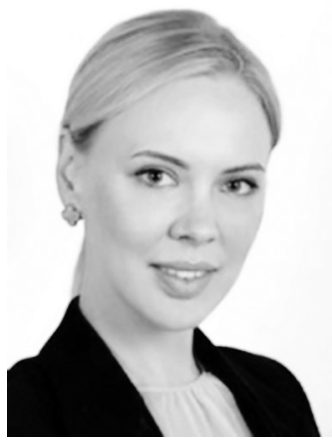

\title{
STATE POLICY IN THE FIELD OF PREVENTING AND COMBATING GENDER- BASED VIOLENCE: NATIONAL AND INTERNATIONAL EXPERIENCE
}

\section{HRYTSAI Iryna - Professor of the Department of General Legal Disciplines of Dnipropetrovsk State University of Internal Affairs, Doctor of Law, Associate Professor УДК 34-055.2 \\ DOI 10.32782/LAW.UA.2020.3.1}

\begin{abstract}
The article considers the peculiarities of national and international experience of state policy in the field of preventing and combating gender-based violence. The importance of gender policy is due to global political processes, international obligations of countries, contradiction of the domestic legal framework in this direction, lack of clear mechanisms for implementing a comprehensive gender approach in state policy. It is emphasised that legal and regulatory structures that support gender equality help to reduce violence at the international and national levels.
\end{abstract}

Emphasis is placed on the fact that Ukraine needs a National Action Plan to combat genderbased violence. In this Plan, it is expedient to clearly delineate the competence of ministries, local governments, health care institutions, public organizations and other structures that will be identified as responsible for this area. Particular attention should be paid to the experience of the European Union in the methods of collecting statistics and processing them.

It is highlighted that it is necessary to introduce and ensure the exchange of experience between states in the context of international standards for combating gender-based violence. This will ensure effective cooperation between states and interaction of their various structures. An important task for each country is to implement a national anti-crisis programme to combat gender-based violence.

The accent is put on the need to introduce a comprehensive system of measures to prevent gender-based violence, amending existing legislation and strengthening accountability for non-compliance. Citizens' awareness of gender- based violence should also be systematically raised by introducing special educational programmes in educational institutions, starting with schools. It is also possible to introduce a gender component as a qualifying feature of crimes and, as a consequence, to increase responsibility for crimes committed on a gender basis.

Key words: state policy, gender equality, violence, gender-based violence, domestic violence, discrimination, prohibition.

Today in Ukraine and in other countries of the world, which contribute to the establishment of gender balance at different levels, the issue of development and implementation of gender policy as an effective dimension of the social structure of society is relevant, taking into account previous achievements and new challenges. Ensuring equal participation of women and men in public activities is a complex and multi-vector problem. The importance of gender policy is due to global political processes, international obligations of countries, contradiction of the domestic legal framework in this direction, lack of clear mechanisms for implementing a comprehensive gender approach in state policy.

Ukraine's state policy in the fight against gender-based violence plays an important role in public life. The basis of gender-based violence is social, economic, demographic, and political instability. Today, the legal literature actively examines the issue of gender-based violence in Ukraine, but not enough attention is paid to the question of how to counteract this 


\section{Теорія, історія держави і права, конституційне право}

type of violence in practice. It is important to construct an appropriate strategy, tactics and multi-alternative mechanisms to ensure it.

The subject of violence is the subject of research by scientists from various fields - philosophy, sociology, political science, psychology, medicine, law and others. Various aspects of state policy and the mechanism of prevention and counteraction to gender-based violence have been considered in the works of such foreign and domestic scientists as V. Arkhipov, N. Anishchuk, N. Bolotina, S. Bratel, M. Buromenskyi, A. Galai, O. Golotsvan, S. Grechaniuk, M. Davtian, I. Demchenko, O. Dashkovska, L. Zavadska, P. Zborovska, L. Kobelianska, L. Kormych, I. Lavrynchuk, M. Laktionova, I. Lysiuk, K. Levchenko, O. Matviienko, T. Martseniuk, T. Melnyk, L. Nalyvaiko, R. Opatskyi, O. Rudnieva, M. Tomashevska, Y. Cherniak, G. Khrystova, S. Yevchenko, M. Yevsiukova and others.

Ukraine's European civilizational choice, which took place as a result of the Revolution of Dignity, posed a number of challenges to Ukrainian society, without adequate answers to which EU accession would remain a rather distant prospect. One of such challenges is the genderization of the social life of Ukrainians [1, p. 58]. At the same level as this issue, there is the issue of combating gender-based violence in Ukraine. The urgency of studying the mechanism of combating gender-based violence in Ukraine, studying international experience on this issue and ways to implement the latter in Ukraine is explained by the fact that genderbased violence reflects gender inequality between men and women, moreover, exacerbates it, undermines human health and safety.

According to a 2018 sociological survey by GfK Ukraine on violence in Ukrainian families, up to $44 \%$ used domestic violence during their lifetime $30 \%$ in childhood and half of children experienced it in adulthood); $33 \%$ of women and $23 \%$ of men have experienced violence in adulthood, and $34 \%$ of men and $27 \%$ of women have experienced violence in childhood. More than $70 \%$ of victims of violence did not turn to anyone for help, the rest mostly turned to other relatives, and only $10 \%$ turned to law enforcement for help [2, p. 83]. Violence is a social phenomenon that exists as an element of social relations - interpersonal, intergroup, interethnic, interstate [3, p. 80]. Gender violence is a global problem of the modern unstable world [4, p. 120]. Most cases of violence against women are perpetrated by men as a result of an imbalance in maintaining gender parity in society. However, it is important to preserve the gender aspect of this issue as a confirmation of the fact of inequality in the relationship between men and women.

Given that gender-based violence has various manifestations (rape, sexual harassment at work, coercion to abortion, ban on intercourse with other men, ban on work, trafficking in women, domestic violence, etc.) [5], all states of the world oppose such violence at the legislative level, taking into account the needs of society at a certain historical stage.

Thus, in Italy in 2010 the National Action Plan on gender-based violence and harassment was adopted. The most specific legislation on the protection of women against gender-based violence is the Law of April 5, 2001 on Measures against Domestic Violence [6]. This law establishes protective measures for victims of both civil and criminal offences. In particular, the law introduced measures to separate the suspect from the victim.

The special Organic Law on Integrated Protection Measures against Gender-based Violence in Spain was adopted on December 28, 2004 [7]. For the first time, in the Spanish legislation they have focused on gender-based violence, which is defined as discrimination, inequality and power relations between men and women. This Law contains measures on sensitivity, protection and detection of gender-based violence. The peculiarity of the Law is that almost every sphere of human life has been covered in order to determine the mechanism for combating gender-based violence. Combating gender-based violence in Spain begins with the introduction of certain training courses in specialized schools: from an early age, the child understands what exactly gender-based violence is and how to resist it.

To illustrate the German experience, reference should be made to the Civil Protection against Violation Act (Gewaltschutzgesetz - GewSchG). Security warrants do not require or depend on any of these relationships, but 
may be used to ensure the safety of any person who intentionally, criminally harms another person's body, health, or freedom. This provision also directly concerns the prosecution and threat of bodily harm or unlawful restraint. In these cases, eviction orders are also possible if the victim and the perpetrator live together. The duration of the eviction depends on the ownership of the apartment or lease agreement (rented together, only one partner) and is up to 6 months. Both types of orders can be issued as a temporary order, in an expedited manner. These orders are issued to prevent further violence [8].

Under the Dutch law, the court may apply the "contact procedure", which provides that the offender is prohibited from addressing the victim in any way. Another option that can be applied at the same time is the "straat-en / of gebiedsverbod". After such a decision has been made, the offender is no longer allowed to come to the street where the victim lives or to be present in a certain area. Most often, this issue is mentioned in the decisions in such a way as to ensure maximum safety for the victim during his daily activities, while minimizing the freedom of movement of the offender [9, p. 17]. A hospital order is a unique provision in criminal law where an offender who has a disorder of a psychological, mental or sexual nature and is diagnosed with a high risk of recidivism is detained during intensive forensic psychiatric treatment. The duration of this type of detention is never determined in advance, but depends on whether the offender is considered curable [10].

An important milestone in overcoming gender-based violence in Georgia is the 2006 Law on the Prevention of Domestic Violence, Protection of and Assistance to Victims of Domestic Violence. A restraining order issued by the police restricts the offender's interaction with the victim for a month. A restraining order becomes a protective order (to protect against persecution) for a period of six to nine months if it is approved by a court. However, in many cases the court refuses to make a decision or rejects the request. For example, in 2014, the police issued 902 restraining orders, but the court issued only 87 protective warrants. According to the Ministry of Internal Affairs, in the first six months of 2019 (January-June) 5399 restraining orders were issued, and in the first six months of $2018-3292$ [11]. To protect women further in the field of marriage, in 2014 coercion to marry was recognized as a crime, and now the marriage of a person under the age of 18 requires court approval [12, p. 163].

Responding to and preventing genderbased violence is a cornerstone of the US government's commitment to human rights, promoting gender equality, and empowering women and girls. In 2012, the President of the United States signed an Order on Preventing and Responding to Violence against Women and Girls Globally. This Strategy defines gender-based violence as violence that is directed at a person on the basis of his or her biological sex, gender identity or commitment to socially defined norms of masculinity and femininity. Gender-based violence includes physical, sexual and psychological violence; threats; coercion; arbitrary imprisonment; economic deprivation, regardless of whether it occurs in public or private life.

The strategy for combating gender-based violence in the United States is as follows: 1) institutionalization of coordination of genderbased violence, which includes interdepartmental and intra-agency coordination, ensuring cooperation with other stakeholders; 2) integration of measures to prevent gender-based violence and respond to the work of the US government; 3) collection, analysis and use of data and research to strengthen gender-based violence prevention and response; setting priorities for monitoring and evaluation of US government programmes; identification and exchange of promising practices, lessons and research within interagency and external partners; 4) launching government programmes to prevent violence in the US government [13]. The experience of the United States is a clear example of how to interact and work in order to eradicate gender-based violence in society.

Preventing gender-based violence requires a comprehensive approach by the state and civil society at all levels. Legal and regulatory structures that support gender equality contribute to the reduction of violence at the international and national levels. More and more countries around the world are introducing such laws 


\section{Теорія, історія держави і права, конституційне право}

and policies to prevent this type of violence. In the international and regional spheres, stakeholders coordinate efforts to achieve systematic change, share evidence of effective action, and provide support for policy and social development to reduce violence.

Ukraine is also taking all necessary measures to combat gender-based violence and eradicate it. So, in order to immediately respond to gender-based violence and assistance to victims, the Cabinet of Ministers of Ukraine adopted a resolution dated 22 August, 2018 "On approval of the procedure for interaction of entities implementing measures to prevent and combat domestic violence and violence on the basis of sex". This act defines the mechanism of interaction of entities implementing measures in the field of preventing and combating domestic violence and gender-based violence, aimed at providing a comprehensive integrated approach to overcoming violence and promoting the rights of victims of violence by preventing violence, effective response on the facts of violence, providing assistance and protection to victims, ensuring compensation for damage, proper investigation of the facts of violence and bringing perpetrators to justice [14].

In addition, the government approved a resolution dated 22 august, 2018 "On approval of the standard regulations on the mobile brigade of social and psychological assistance to victims of domestic violence and / or genderbased violence". The work of such mobile teams helps to increase the capacity of local communities to provide access to quality social and rehabilitation services and emergency response to violence in order to prevent and combat the latter [15]. Combating gender-based violence is a major health issue.

Preventing gender-based violence means taking steps to end such violence from the outset (e.g., expanding activities that promote gender equality, working with communities, especially men and boys, to address issues that contribute to the spread of gender-based violence, etc.) [16]. The example of the United States shows a vivid experience in combating gender-based violence, which is divided into certain stages, which in turn are interconnected.

European Union Directive 2011/99 / EU [17] aims to protect victims, including victims of gender-based violence. The adoption by the European Union of a special Directive is an important legal measure to combat such violence and to protect victims, taking into account the specifics of each type of crime concerned and the forms / types of gender-based violence. Gender-based violence requires a concrete social, legal and political response to identify approaches and methods to combat it.

Effective prevention and response to violence requires coordinated measures in many areas of human life, at least in medical, social, legal, law enforcement. The general coordination responsibilities of the multisectoral approach are strategic planning; data collection and information management; resource mobilization and accountability; functional division of labor; negotiating and supporting effective action to both prevent and respond. In turn, specific coordination activities include: exchange of information on resources, guidelines and other materials; exchange of unexpected data on sexual incidents; discussion and solution of prevention and response problems; joint monitoring and evaluation; current programme and policy development [18].

Special attention needs to be paid to the study of gender-based violence during emergencies, armed conflicts, etc. In such circumstances, a number of working groups are set up to ensure that all actors involved in a given sector work in a coordinated manner and ensure that international standards are met.

Combating gender-based violence usually consists of three categories: primary prevention - preventing the spread of gender-based violence against women and girls who have no experience of violence against themselves and preventing new cases among those who have already experienced it; secondary prevention - preventing further violence and / or providing support to victims of violence. This usually includes the level of care provided to victims of health violence and other social services; tertiary prevention - long-term support for victims of legal and psychosocial violence [19]. For any of these categories to be effective, a comprehensive approach is needed to not only reduce the incidence of gender-based violence, but also to change the social norms and gender disparities 
that allow for the existence of such phenomena as gender-based violence.

In summary, it should be noted that public policy and the mechanism for combating gender-based violence need to be improved in order to ensure gender equality. At the legislative level, it is necessary to develop a set of normative legal acts, defining the mechanism of interaction of executive bodies that will be responsible for combating gender-based violence.

The formation of a mechanism to combat gender-based violence at the legislative level should become an integral part of the process of reforming the Ukrainian legal system as a whole in accordance with international law and taking into account the declared course of integration into the European Union.

Summing up the results of the study, the following conclusions should be drawn.

1. Prevention of gender-based violence requires an integrated approach at all levels of society. Legal and regulatory structures that support gender equality contribute to the reduction of violence at the international and national levels. It is necessary to introduce and ensure the exchange of experience between states in the context of international standards for combating gender-based violence. This will ensure effective cooperation of states and cooperation of their various structures, departments, ministries in the process of implementation of the National Action Plan to combat gender-based violence in Ukraine.

2. The Ukrainian state needs a National Action Plan to combat gender-based violence. The formation of the National Action Plan for the Implementation of Gender Equality, Prevention and Counteraction to Gender-Based Violence is entrusted to a specially authorized central executive body for equal rights and opportunities for women and men. In this Plan, it is expedient to delineate clearly the competence of ministries, local governments, health care institutions, public organizations and other structures that will be identified as responsible for this area. Particular attention should be paid to the experience of the European Union in the methods of collecting statistics and processing them.

3 . The modern state is an open system that constantly interacts with various international organizations and civil society for the stable functioning of society. An important task for each country is to implement a national anticrisis programme to combat gender-based violence. The purpose of such a programme is to control all aspects of the crisis and respond in a timely manner to changing conditions. Depending on the type (form) of gender-based violence and its scale or specificity, anti-crisis measures are determined, concentration on key tasks is increased, changes are introduced to level the inadequate information to society and eradicate gender-based violence.

4. It is important to introduce a comprehensive system of measures for the prevention of gender-based violence with amendments to current legislation and strengthening the responsibility for non-compliance with the latter. Today, unfortunately, there are still cases when the tyrant boss keeps his subordinates in fear. Such a situation should become unacceptable even on a mental level. Obviously, legislative changes alone are not enough to achieve this goal. Citizens' awareness of gender-based violence should also be systematically raised by introducing special educational programmes in educational institutions, starting with schools. The positions of psychologists who will work in this direction should also be introduced separately, and where psychologists already exist, such responsibilities should be assigned to them. It is necessary to establish close cooperation with law enforcement agencies aimed at detecting and preventing cases of gender-based violence. To implement this issue in practice, it is necessary to develop an act that will regulate the mechanisms of such interaction.

5. It is also possible to introduce a gender component as a qualifying feature of crimes and, as a consequence, to increase responsibility for crimes committed on a gender-based basis. Establishing increased accountability for gender-based crimes will help reduce the number of such crimes through tougher sanctions. After all, it is known that most victims of street robberies, rapes, bullying (including psychological) are women. Thus, a significant proportion of such crimes are based on gender. At the same time, one should not ignore sexual harassment and manifestations of sexism, which occur both in everyday life and in pro- 


\section{Теорія, історія держави і права, конституційне право}

fessional activities. Such changes to the legislation should be implemented comprehensively, with broad and all-inclusive media coverage, in order to accelerate the community's continued understanding that gender-based violence is an important issue that requires increased attention at the current stage of society's development. Consolidation of society and political forces in order to reform the law is necessary to combat gender-based violence fully and effectively. Men and women need to be aware of the need for such changes in modern society.

\section{Literature}

1. Грабовська I., Наливайко А., Обушний М. Гендер в освітньому процесі українських вишів як філософсько-світоглядна складова конфліктизаційної проблематики. Украйнознавчий альманах. 2020. Вип. 26. C. $58-65$.

2. Старчук О. Заходи запобігання та протидії домашнього насильства: український досвід в міжнародному контексті. Icторико-правовий часопис. 2019. № 2. С. 83-87.

3. Зінсу О. І. Соціальні та юридичнопсихологічні аспекти домашнього насильства. Науковий вісник Начіональної академї внутрішніх справ. 2020. № 1. С. 79-87.

4. Ерохина $\lambda$. Д. Гендерология и феминология: учеб. пособ. Москва: Флинта: Наука, 2009. 384 с.

5. Савчук О. Аспекти протидії гендерному насильству - практика в Українію Інформаційна довідка, підготовлена Европейським інформаційно-дослідницьким центром на запит Комітету Верховної Ради України. 11 с. URL: http://radaprogram. org/sites/default/files/infocenter/piblications/ aspekty_protydiyi_gendernomu_nasylstvu.pdf

6. Misure contro la violenza nelle relazioni familiari. Gazzetta Ufficiale. № 98. 2001. URL: http://www.gazzettaufficiale.it/eli/ id/2001/04/28/001G0209/sg

7. Organic Law $1 / 2004$ of 28 December on Integrated Protection Measures against Gender Violence. Spain. URL: http://justiciadegenero. com/en/organic-law-12004-of-28-decemberon-integrated-protection-measures-againstgender-violence-spain/

8. Gesetz zum zivilrechtlichen Schutz vor Gewalttaten und Nachstellungen.
Gewaltschutzgesetz vom 11. Dezember 2001 (BGBl. I S. 3513), das durch Artikel 4 des Gesetzes vom 1. März 2017 (BGBl. I S. 386) geändert worden ist. URL: https://www. gesetze-im-internet.de/gewschg/GewSchG. pdf

9. Feasibility study national legislation on gender violence and violence against children. Report on the Netherlands. 2010. URL: https:// eige.europa.eu/it/node/2546?lang $=$ it

10. Legal Definitions in the EU Member States. Netherlands. URL: https://eige.europa. eu/gender-based-violence/regulatory-andlegal-framework/legal-definitions-in-the$\mathrm{eu} ? \mathrm{c}[]=\mathrm{NL}$

11. Georgia: Criminalization of Domestic Violence. Global Legal Monitor. URL: http:// www.loc.gov/law/foreign-news/article/georgiacriminalization-of-domestic-violence/.

12. Грідіна Н. Ю. Протидія гендерно обумовлене насильству: досвід Грузії та можливості його використання в Україні. Наукові записки [Центральноукрайнського державного педагогічного університету імені Володимира Винниченка]. Серія: Право. 2020. Вип. 8. C. 160-166.

13. United States Strategy to Prevent and Respond to Gender-based Violence Globally. 2 012.60 p. URL: https://pdf.usaid.gov/pdf_docs/ PDACT888.pdf

14. Про затвердження Порядку взаємодії суб’єктів, що здійснюють заходи у сфері запобігання та протидії домашньому насильству і насильству за ознакою статі: Постанова Кабінету Міністрів України від 22.08.2018 № 658. Обічійний вісник Украӥни. 2018. № 69. Ст. 2332.

15. Про затвердження Типового положення про мобільну бригаду соціально-психологічної допомоги особам, які постраждали від домашнього насильства та/ або насильства за ознакою статі: Постанова Кабінету Міністрів України від 22.08.2018. № 654. Офічійний вісник Украйни. 2018. № 69. Ст. 2331.

16. Guidelines for Integrating GenderBased Violence Interventions in Humanitarian Action: Reducing risk, promoting resilience and aiding recovery. Inter-Agency Standing Committee, 2015. 366 p. URL: http://gbvguidelines.org/wp/wp-content/ 
uploads/2015/09/2015-IASC-Gender-basedViolence-Guidelines_lo-res.pdf.

17. Directive 201 1/99/EU of the European Parliament and of the Council of 13 December 2011 on the European protection order. URL: https://eur-lex.europa.eu/legal-content/EN/ TXT/?uri = celex\%3A32011L0099

18. Elimination of Violence Against Women. Commission on Human Rights Resolution 2004/46. Office of the high commissioner for human rights. Geneva, 2004. $8 \mathrm{p}$.

19. Directive 2011/99/EU of the European Parliament and of the Council of 13 December 2011 on the European protection order. URL: https://eur-lex.europa.eu/legal-content/EN/ TXT/?uri=celex\%3A32011L0099

\section{Грицай Ірина Олегівна ДЕРЖАВНА ПОЛІТИКА У СФЕРІ ПРОФІЛАКТИКИ І БОРОТЬБИ 3 ГЕНДЕРНИМ НАСИАЬСТВОМ: НАЦІОНААЬНИЙ І МІЖНАРОДНИЙ ДОСВІД}

У статті розглянуто особливості національного та міжнародного досвіду державної політики у сфері запобігання та протидії гендерно обумовленому насильству. Вагомість тематики гендерної політики зумовлена світовими політичними процесами, міжнародними зобов'язаннями країн, суперечністю вітчизняної нормативно-правової бази у цьому напрямі, відсутністю чітких механізмів запровадження комплексного гендерного підходу у політиці держави. Наголошено, що правові та регуляторні структури, які підтримують гендерну рівність, сприяють зменшенню насильства на міжнародному та національному рівнях.
Акцентовано увагу, що Україна потребує наявності Національного плану дій щодо боротьби з насильством, заснованим на гендері. У вказаному Плані доцільно чітко розмежувати компетенцію міністерств, органів місцевого самоврядування, закладів охорони здоров'я, громадських організацій та інших структур, які будуть визначені відповідальними за цей напрям. Особливу увагу слід приділити досвіду Європейського Союзу у методах збору статистичних даних та їх обробки.

Підкреслено, що необхідно запровадити та забезпечити обмін досвідом роботи між державами в умовах дії міжнародних стандартів протидії гендерно обумовленому насильству. Це забезпечить ефективну співпрацю держав та взаємодію їхніх різних структур. Важливим завданням кожної країни $€$ запровадження національної антикризової програми боротьби з насильством, заснованим на гендері.

Наголошено на необхідності ввести комплексну систему заходів 3 профілактики гендерно обумовленого насильства із внесенням змін до чинного законодавства та посилення відповідальності за недотримання останнього. Слід також систематично підвищувати обізнаність громадян з питань гендерно обумовленого насильства шляхом введення спеціальних освітніх програм у закладах освіти, починаючи зі шкіл. Також можливим є запровадження гендерної компоненти як кваліфікуючої ознаки злочинів i, як наслідок, - посилення відповідальності за злочини, вчинені на гендерно обумовленому підгрунті.

Ключові слова: державна політика, гендерна рівність, насильство, гендерно обумовлене насильство, домашнє насильство, дискримінація, заборонний припис. 